\title{
Markers of cognitive impairment in patients with type 2 diabetes
}

\section{Indicatori ai disfuncţiei cognitive la pacienţii cu diabet zaharat tip 2}

\author{
Simona Cernea ${ }^{1,2, *}$, Floredana-Laura Şular ${ }^{3}$, Adina Huţanu ${ }^{3,4}$, Septimiu Voidăzan ${ }^{5}$ \\ ${ }^{1}$ Department M3/Internal Medicine IV., University of Medicine and Pharmacy, Tîrgu Mureș, Romania, \\ ${ }^{2}$ Diabetes, Nutrition and Metabolic Diseases Outpatient Unit, Emergency County Clinical Hospital, Tîrgu \\ Mureş, Romania, ${ }^{3}$ Department M2/Laboratory Medicine, University of Medicine and Pharmacy, Tîrgu \\ Mureș, Romania, ${ }^{4}$ Central Laboratory, Emergency County Clinical Hospital, Tîrgu Mureș, Romania, \\ ${ }^{5}$ Department M2/Division of Epidemiology, University of Medicine and Pharmacy, Tîrgu Mureș, Romania
}

\begin{abstract}
Background. The study aimed to evaluate the correlations of cognitive function with metabolic, nutritional, hormonal and immunologic parameters in patients with type 2 diabetes (T2D), in order to identify markers of cognitive impairment. Material and methods. This cross-sectional study included 216 T2D patients and 23 healthy individuals (HC). The cognitive status was evaluated by the MoCA test. From HC and 145 T2D patients several parameters were also determined: C-peptide, vitamin B12, high-sensitivity CRP (by chemiluminescent immunometric assay), HbAlc, lipids, cortisol, TSH, Mg (by a Cobas 6000 analyzer), glucose (by glucose-oxidase method) and leptin and adiponectin (by ELISA method). Statistical significance was set at $p<0.05$.

Results. There was a significant difference in the MoCA scores between HC and T2D groups (26.0(17.0-29.0) vs. 23.0(13.031.0) points; $p:$ 0.004). T2D patients with cognitive dysfunction were significantly older and less formally educated $(p<0.0001)$. Age negatively correlated with MoCA scores (-0.31; 95\%CI:-0.42,-0.18; $p<0.0001)$. T2D patients had significantly lower visuospatial/executive (4.0(0.0-5.0) vs. 5.0(2.0-5.0) points; $p$ : 0.04) and delayed recall scores (2.0(0.05.0) vs. 3.0(1.0-5.0) points; $p$ : 0.03) and lower serum Mg concentrations (0.81(0.12-0.99) vs. 0.92(0.41-1.35) mmol/l, $p<$ $0.0001)$. Serum Mg levels positively correlated with MoCA scores (0.24, 95\%CI: 0.07, 0.39; $p: 0.003)$ and with visuospatial/executive (0.30; 95\% CI: 0.14, 0.45; $p$ : 0.0002) and naming functions (0.18; 95\% CI: 0.01, 0.34; $p: 0.02)$.

Conclusions. Patients with T2D had significant cognitive impairment, with decrements in the visuospatial/executive and delayed recall domains. Younger age and higher education correlated with better cognitive function. Serum Mg levels correlated positively with overall cognitive function and with visuospatial/executive and naming domains.
\end{abstract}

Keywords: type 2 diabetes, cognitive function, cognitive domains, serum magnesium, age.

\section{Rezumat}

Introducere. Scopul studiului a fost evaluarea corelaţillor funcţiei cognitive cu parametri metabolici, nutriţionali, hormonali şi imunologici la pacienţii cu diabet zaharat tip 2 (DZ2), pentru identificarea unor markeri ai disfuncţiei cognitive.

* Corresponding author: Simona Cernea, Department M3/Internal Medicine IV., University of Medicine and Pharmacy, Gh. Marinescu 38, Tîrgu Mureș, Romania, e-mail: simona.cernea@rrml.ro 
Material şi metode. Acest studiu transversal a inclus 216 pacienţi cu DZ2 şi 23 subiecţi sănătoşi (CS). Statusul cognitiv a fost evaluat cu testul MoCA. La CS şi 145 pacienţi DZ2 s-au determinat parametrii: peptid-C, vitamina B12, PCR ultra-sensibilă (prin metoda imunometrică chemiluminiscentă), HbAlc, lipidele, cortizolul, TSH, Mg (cu analizor Cobas 6000), glucoza (prin metoda glucozo-oxidazei), leptina şi adiponectina (prin metoda ELISA). Semnificația statistică a fost stabilită la $p<0.05$.

Rezultate. Scorurile MoCA ale grupurilor CS şi DZ2 au fost semnificativ diferite (26.0(17.0-29.0) vs. 23.0(13.031.0) puncte; $p$ : 0.004). Pacienţii cu DZ2 şi disfuncţie cognitivă au fost mai vârstinici şi cu educaţie fomală mai redusă $(p<0.0001)$. Vârsta s-a corelat negativ cu scorul MoCA (-0.31; 95\%CI:-0.42,-0.18; $p<0.0001)$. Pacienţii cu DZ2 au avut scoruri vizuospatial/executive (4.0(0.0-5.0) vs. 5.0(2.0-5.0) puncte p: 0.04) şi reamintire (2.0(0.05.0) vs. 3.0(1.0-5.0) puncte; $p$ : 0.03) semnificativ mai mici şi concentraţii reduse ale Mg seric (0.81(0.12-0.99) vs. 0.92(0.41-1.35) mmol/l, $p$ < 0.0001). Nivelele Mg seric s-au corelat pozitiv cu scorul MoCA (0.24, 95\%CI: $0.07,0.39 ; p: 0.003)$ şi cu funcţiile vizuospaţial/executivă $(0.30 ; 95 \%$ CI: 0.14, 0.45; p: 0.0002) şi denumire (0.18; 95\%CI: 0.01, 0.34; p: 0.02).

Concluzii. Pacienţii cu DZ2 au prezentat disfuncţie cognitivă semnificativă, cu diminuarea funcţiilor vizuospaţial/ executivă şi reaminitire. Vârsta tânără şi educaţia superioară s-au corelat cu funcţie cognitivă mai bună. Nivelele Mg seric s-au corelat pozitiv cu funcţia cognitivă generală şi domeniile vizuospațial/executiv şi denumire.

Cuvinte cheie: diabet zaharat tip 2, funcţia cognitivă, domenii cognitive, magneziu seric, vârsta.

Received: $8^{\text {th }}$ March 2016; Accepted: 10 ${ }^{\text {th }}$ May 2016; Published: $3^{\text {th }}$ June 2016.

Data indicate that patients with type 2 diabetes (T2D) are at increased risk of developing cognitive dysfunction/ dementia, yet the pathophysiological mechanisms that underlie and correlate these two conditions have not been completely elucidated (1). The literature suggests several risk factors possibly associated with or contributing to the diabetes-related cognitive impairment/ dementia, such as chronic hyperglycemia with accumulation of advanced glycation end products, repetitive hypoglycemic episodes, hyperinsulinemia and insulin resistance (with associated impairment in insulin signaling in the brain), impaired amyloid clearance with abnormal cerebral amyloid deposition, dyslipidemia, oxidative stress, inflammation, hormonal factors or vascular dysfunction (2). Cognitive impairment results in negative health outcomes including poor diabetes management and decreased life expectancy (3).

The aim of this study was to evaluate the correlations between cognitive function, as evaluated by the Montreal Cognitive Assessment test (MoCA), and a panel of metabolic, nutritional, hormonal, and immunologic parameters in sub- jects with T2D, in an attempt to identify biomarkers of cognitive impairment in this patient population. Of a larger number of parameters of potential interest for our purpose, we chose those that are diabetes-specific (e.g. C-peptide, fasting blood glucose, HbAlc), clinically relevant for patients with T2D (e.g. lipids, adiponectin, leptin, TSH, cortisol) or potentially significant in terms of pathophysiological mechanisms (e.g. nutrients, inflammatory markers).

\section{Material and methods}

This was a cross-sectional study that included patients with T2D regularly seen in the Diabetes, Nutrition and Metabolic Diseases Outpatient Unit of the Emergency County Clinical Hospital in Tîrgu Mureş and age- and gender-matched healthy control (HC) subjects. This evaluation was part of a larger study that included assessment of depression and anxiety, with an additional depression group, but this data are not presented here. We present only the data related to cognitive function. The study was approved by the Ethics Committee of the Emergency County 
Clinical Hospital of Tîrgu Mureş and that of the University of Medicine and Pharmacy of Tîrgu Mureș, and the patients signed an informed consent before participating in the study.

The subjects were included in the study if they were $\geq 30$ years old, either had a previous diagnosis of T2D or were healthy (defined by this protocol as without depression/ T2D), had at least minimal literacy (able to read and write) and were fluent in Romanian language. Exclusion criteria were type 1 , secondary or gestational diabetes (for T2D group), diabetes or depression (for HC group), severe diseases (such as, but not exclusively: severe autoimmune diseases or cancer diagnosed less than 5 years before) for all. Diagnosis of diabetes was set according to the American Diabetes Association (ADA) criteria (4).

The cognitive status was evaluated by the Romanian version of the MoCA test. The permission to use the questionnaire was kindly obtained from Kathleen Gallant, MSOT, on behalf of Dr Ziad Nasreddine, MoCAC Copyright Owner. The MoCA is a cognitive screening test rated on a 30-point scale that also adjusts for the level of education, as for $\leq 12$ grades of formal education 1 point is added. A score $\geq 26$ points is considered normal, 17-25 points denote mild cognitive impairment, $10-16$ points moderate cognitive impairment, while $<10$ points severe cognitive impairment, respectively (5).

The following details were collected from all the participants: demographic (age, gender, ethnicity, residence, socio-economic status, level of education), clinical data (personal and family history, current therapy, blood pressure, heart rate, smoking, alcohol use), and anthropometric measurements (weight, height, waist and hip circumference) obtained. The body mass index (BMI) and waist-to-hip ratio were calculated.

Of 145 patients with T2D and $23 \mathrm{HC}$ subjects fasting blood samples were obtained within two weeks from inclusion in the study. Samples were collected by venipuncture in the morning, between 8.00-9.00 am, after an overnight fast and then immediately centrifuged. Serum was aliquoted and stored at $-80^{\circ} \mathrm{C}$ for subsequent tests. Glycated hemoglobin (HbA1c) samples were stored at $4^{\circ}-8^{\circ} \mathrm{C}$ and analyzed within one week.

C-peptide, vitamin B12, and high-sensitivity C-reactive protein (hsCRP) concentrations were measured by chemiluminescent immunometric assay, according to the manufacturer's instructions (Immulite ${ }^{\circledR} 1000$; Immulite Siemens kits). As stated by the manufacturer, the functional sensitivity of the method for C-peptide was 0.09 $\mathrm{ng} / \mathrm{ml}$ and total coefficient of variation $(\mathrm{CV})$ was $5.5 \%$. For vitamin B12, the total CV for intra-assay precision were $11.3 \%$ and analytical sensitivity was $125 \mathrm{pg} / \mathrm{ml}$. The functional sensitivity of the method for hsCRP was $0.3 \mathrm{mg} / \mathrm{l}$ and total CV was $10.0 \%$.

Leptin and adiponectin were measured by the enzyme-linked immunosorbent assay (ELISA) method (ELISA MiniBos, Biomedica), according to the manufacturers' instructions. The analytical sensitivity for the leptin kit was 1.0 $\mathrm{ng} / \mathrm{ml}$ and the CV for the intra-assay variability were $6.91 \%$ (DRG Instruments, Germany). For the adiponectin kit, the analytical sensitivity was $0.338 \mathrm{ng} / \mathrm{ml}$, while the CV for the intra-assay variability were $3.4 \%$ (Immundiagnostik $\mathrm{AG}$, Bensheim).

HbA1c, lipid parameters (low density lipoprotein (LDL)-cholesterol, high density lipoprotein (HDL)-cholesterol, triglycerides), cortisol, thyroid-stimulating hormone (TSH) and magnesium $(\mathrm{Mg})$ concentrations were determined by the use of a Cobas 6000 analyzer (c501 and e601 modules) (Roche Diagnostics). Total cholesterol was calculated by the Friedewald formula, except when triglyceride values were $>400 \mathrm{mg} / \mathrm{dl}$, in which cases total cholesterol was measured by the same method/ analyzer. The functional sensi- 
tivity for the cortisol kit was $<8.5 \mathrm{nmol} / 1$, while for TSH it was $0.014 \mu \mathrm{IU} / \mathrm{ml}$, as stated by the manufacturer. Blood glucose was measured by the glucose-oxidase method and a mean of the two measurements was calculated.

By using the Homeostasis Assessment Model (HOMA) calculator version 2.2.3, based on fasting glucose and C-peptide concentrations, we estimated the insulin resistance (HOMA IR) and beta cell function (HOMA B\%) (6).

Descriptive statistics were performed for all variables and expressed as mean $\pm \mathrm{SD}$ or median (min-max) for normal or non-normally distributed continuous variables, respectively, and frequency (\%) for categorical variables. Normality of data was checked by Kolomogrov-Smirnov test. Student t test, Mann-Whitney test, ANOVA and Kruskal-Wallis tests were employed to compare means and medians between groups. Fisher's exact test was used for analysis of categorical variables, and the odds ratios (OR) with 95\% confidence interval (CI) were calculated for categorical comparisons. We also used Dunn or Bonferroni multiple comparison post-test to identify the groups between which there were significant differences. Spearman's correlation coefficients were calculated to evaluate the relationship between the variables of interest. Multiple regression analysis was used to evaluate the correlations between more than two variables. All tests were two-tailed and the statistical significance was set at $p<0.05$. Statistical analysis was performed by using GraphPad InStat3.

\section{Results}

The study finally included and analyzed data for 216 patients with T2D and $23 \mathrm{HC}$ individuals who agreed to participate (excluded: 1 patient with secondary diabetes and 5 subjects from the HC group - 2 had depression scores at least at one questionnaire, 3 had blood glucose values of diabetes). These groups were matched for age $(62.2 \pm 7.8$ years in the T2D group vs. $61.6 \pm 7.0$ years in the HC group, $\mathrm{p}>0.05)$ and gender ( $\mathrm{Fe}-$ male/ Male: $61.5 \% / 38.4 \%$ in the T2D vs. $60.9 \% /$ $39.1 \%$ in the HC group, $p>0.05$ ). No significant differences were noted for demographic parameters between the two groups, except for ethnicity: the percentages of Romanians/ Hungarians/ Rroma/ Germans were 74.5\%/ 23.6\%/ 1.9\%/ $0.0 \%$ in the T2D group, and $78.0 \% / 17.4 \% /$ $0.0 \% / 4.3 \%$ in the HC group (p: 0.01 ).

As we showed in a previous report, administration of the MoCA test in patients with T2D conveyed the following results: $54 / 216(25.0 \%)$ had normal cognitive function scores, 149/ 216 (69.0\%) had mild, 13/ 216 (6.0\%) had moderate, and none had severe cognitive dysfunction scores (7). In contrast, in the matched HC group, 11/ 23 (47.8\%) had mild cognitive impairment and $12 / 23$ (52.2\%) had normal cognitive function scores ( $\geq 26$ points), while none had moderate or severe cognitive impairment scores ( $p$ : 0.04). Moreover, there was a significant difference in the median MoCA scores between the two groups (26.0 (17.0-29.0) points in HC vs. 23.0 (13.0-31.0) points in T2D group; p: 0.004).

We then divided the T2D group according to the cognitive function scores. The demographic and clinical data is presented in Table $\mathbf{1 .}$ Even if there was no difference in duration of diabetes between the three groups, patients with cognitive dysfunction were significantly older $(\mathrm{p}<0.0001)$ (Table 1). There was also a significant negative correlation of age with MoCA scores $(-0.31 ; 95 \% \mathrm{CI}:-0.42,-0.18 ; \mathrm{p}<0.0001)$. Male patients with T2D and normal cognitive function scores had higher waist scores compared to the other two DZ groups (Table 1) (p: 0.02 ), but there was no significant correlation between waist and MoCA scores in male T2D patients $(0.18 ; 95 \% \mathrm{CI}:-0.03,0.39 ; \mathrm{p}>0.05)$ or between waist-to-hip ratio and MoCA scores 
Table 1. Demographic and clinical characteristics of T2D patients with and without cognitive impairment.

\begin{tabular}{|c|c|c|c|c|}
\hline & $\begin{array}{l}\text { Moderate cogni- } \\
\text { tive impairment } \\
\quad(n=13)\end{array}$ & $\begin{array}{l}\text { Mild cognitive } \\
\text { impairment } \\
(n=149)\end{array}$ & $\begin{array}{l}\text { Normal cogni- } \\
\text { tive function } \\
\quad(n=54)\end{array}$ & $\mathrm{p}$ value \\
\hline Gender (F/M) (no/\%) & $8(61.5) / 5(38.5)$ & $95(63.8) / 54 /(36.2)$ & $30(55.6) / 24(44.4)$ & $>0.05$ \\
\hline Residence (U/R) (no/\%) & $11(84.6) / 2(15.4)$ & $125(83.9) / 24(16.1)$ & $47(87.0) / 7(13.0)$ & $>0.05$ \\
\hline Age (years) & $69.4 \pm 6.8$ & $62.6 \pm 7.6$ & $59.2 \pm 7.1$ & $<0.0001$ \\
\hline Duration of T2D (years) & $4.0(2.0-25.0)$ & $4.0(0.5-19.0)$ & $4.0(0.5-16.0)$ & $>0.05$ \\
\hline $\begin{array}{l}\text { Education }(\mathrm{no} / \%) \\
<8 \text { classes } \\
<12 \text { classes } \\
\text { High school } \\
\text { Post-secondary school } \\
\text { University } \\
\text { Post-university (master/doctoral) }\end{array}$ & $\begin{array}{l}0(0.0) \\
9(69.2) \\
3(23.1) \\
1(7.7) \\
0(0.0) \\
0(0.0)\end{array}$ & $\begin{array}{l}7(4.7) \\
58(38.9) \\
35(23.5) \\
30(20.1) \\
16(10.7) \\
3(2.0)\end{array}$ & $\begin{array}{l}0(0) \\
5(9.3) \\
21(38.9) \\
6(11.1) \\
19(35.2) \\
3(5.6)\end{array}$ & $0.0001^{<}$ \\
\hline $\begin{array}{l}\text { Ethnicity (no/\%): } \\
\text { Romanian } \\
\text { Hungarian } \\
\text { Rroma }\end{array}$ & $\begin{array}{l}10(76.9) \\
3(23.1) \\
0(0.0)\end{array}$ & $\begin{array}{l}110(73.8) \\
37(24.8) \\
2(1.3) \\
\end{array}$ & $\begin{array}{l}43(79.6) \\
11(20.4) \\
0(0.0)\end{array}$ & $>0.05$ \\
\hline $\begin{array}{l}\text { Social status (no/\%): } \\
\text { Married/life-partner } \\
\text { Never married/ widower/divorced }\end{array}$ & $\begin{array}{l}9(69.2) \\
4(30.8)\end{array}$ & $\begin{array}{l}109(73.2) \\
40(26.8) \\
\end{array}$ & $\begin{array}{l}36(66.7) \\
18(33.3) \\
\end{array}$ & $>0.05$ \\
\hline BMI $\left(\mathrm{kg} / \mathrm{m}^{2}\right)$ & $30.9 \pm 2.8$ & $32.1 \pm 5.6$ & $33.5 \pm 5.6$ & $>0.05$ \\
\hline $\begin{array}{l}\text { Waist (cm) } \\
\text { M } \\
\text { F }\end{array}$ & $\begin{array}{l}109.3 \pm 5.1 \\
105.2 \pm 5.8\end{array}$ & $\begin{array}{l}108.9 \pm 9.0 \\
105.4 \pm 12.8\end{array}$ & $\begin{array}{l}116.2 \pm 14.1 \\
107.5 \pm 11.6\end{array}$ & $\begin{array}{l}0.02 \\
>0.05\end{array}$ \\
\hline $\begin{array}{l}\text { Waist-to hip ratio } \\
\text { M } \\
\text { F }\end{array}$ & $\begin{array}{l}1.02 \pm 0.04 \\
0.97 \pm 0.04\end{array}$ & $\begin{array}{l}1.03 \pm 0.05 \\
0.95 \pm 0.07\end{array}$ & $\begin{array}{l}1.06 \pm 0.07 \\
0.95 \pm 0.06\end{array}$ & $\begin{array}{l}>0.05 \\
>0.05 \\
\end{array}$ \\
\hline $\begin{array}{l}\mathrm{SBP}(\mathrm{mmHg}) \\
\text { DBP }(\mathrm{mmHg}) \\
\text { Heart rate }(\text { beats } / \mathrm{min})\end{array}$ & $\begin{array}{l}142.1 \pm 20.3 \\
76.5 \pm 10.6 \\
76.0 \pm 9.0\end{array}$ & $\begin{array}{l}137.3 \pm 19.5 \\
77.6 \pm 10.4 \\
77.6 \pm 10.4 \\
\end{array}$ & $\begin{array}{l}137.1 \pm 17.4 \\
80.2 \pm 10.3 \\
80.2 \pm 10.3\end{array}$ & $\begin{array}{l}>0.05 \\
>0.05 \\
>0.05\end{array}$ \\
\hline $\begin{array}{l}\text { Smoking } \\
\text { Status }\end{array}$ & & & & \\
\hline $\begin{array}{l}\text { Smoker (no) } \\
\text { Ex-smoker (no) } \\
\text { Non-smoker (no) } \\
\text { Exposure (packs-years) }\end{array}$ & $\begin{array}{l}1 \\
3 \\
9 \\
0.0(0.0-135.0)\end{array}$ & $\begin{array}{l}17 \\
57 \\
75 \\
0.0(0.0-90.0)\end{array}$ & $\begin{array}{l}9 \\
25 \\
20 \\
5.35(0.0-66.0)\end{array}$ & $>0.05$ \\
\hline
\end{tabular}

data represents mean $\pm S D$ or median (min-max), unless otherwise specified. 
(0.16; 95\%CI: $-0.05,0.37 ; \mathrm{p}>0.05)$. The same remained true when MoCA scores were analyzed in correlation with waist for all T2D patients (0.02; 95\%CI: $-0.09,0.17 ; p>0.05)$, and as well as with their waist-to-hip ratio and BMI (0.04; 95\%CI: $-0.09,0.17$ and 0.05 ; $95 \% \mathrm{CI}:-0.07$, $0.19 ; \mathrm{p}>0.05$ for both).

There was a significant difference between the three cognitive function groups with regards to the level of education $(\mathrm{p}<0.0001)$ (Table 1). Moreover, when T2D patients were stratified according to the level of education, there was a significant difference between MoCA scores ( $<8$ grades: $18.3 \pm 2.6$ points, $<12$ grades: 21.2 \pm 3.5 points, high school: $23.8 \pm 3.4$ points, post-secondary school: $23.0 \pm 2.9$ points, university: $24.6 \pm 2.6$ points, post-graduate educa- tion: $26.0 \pm 2.6$ points; $\mathrm{p}<0.0001$ ). For the purpose of comparing the MoCA scores in patients with T2D and HC, data were grouped in three levels of education ( $<12$ grades; high school \& post-secondary school; university \& post-graduate education), because the number of subjects in the HC group was relatively small. The difference in MoCA scores was significant only in patients with T2D, but not in HC (Figure 1). In addition, patients with T2D and high-school \& post-secondary school education had significantly lower scores compared to HC subjects with the same level of education (24.0 (15.0-31.0) points vs. $26.0(20.0-28.0)$ points, p: 0.01) (Figure 1).

The MoCA test evaluates several cognitive domains: visuospatial/ executive, naming, attention,

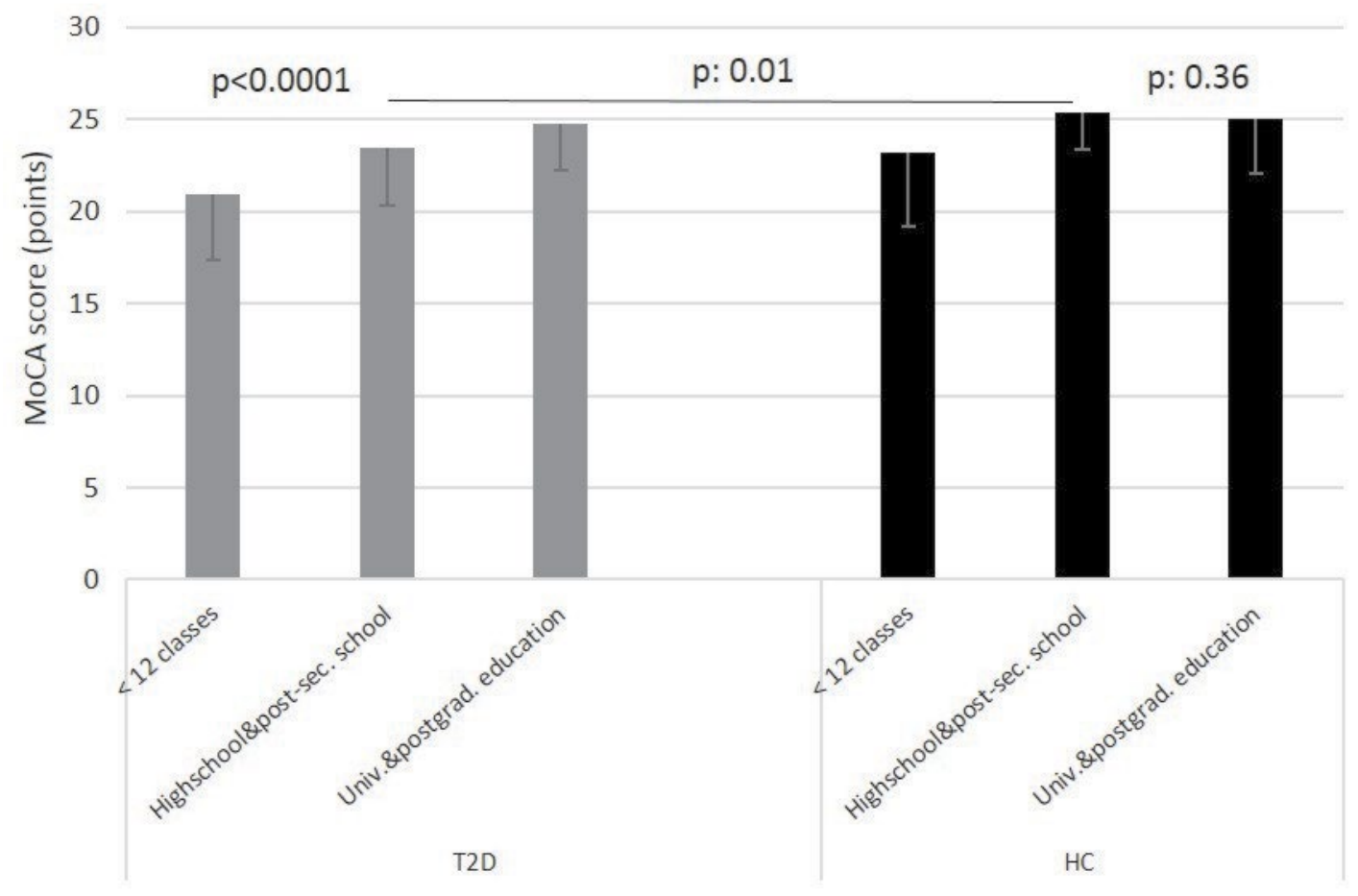

Figure 1. The cognitive function assessed by MoCA test according to years of formal education in patients with T2D (black bars) and HC (grey bars) (data grouped in 3 categories of education) (data represent mean $\pm \mathrm{SD}$ ) 
language, abstraction, delayed recall, orientation. Subjects with T2D presented significantly lower scores compared to HC group for the visuospatial/ executive domain (4.0 (0.0-5.0) points in T2D vs. $5.0(2.0-5.0)$ points in $\mathrm{HC}$; p: 0.04$)$ and for the de- layed recall domain $(2.0(0.0-5.0)$ points in T2D vs. 3.0 (1.0-5.0) points in HC; p: 0.03) (Figure 2a).

Although there was no gender difference between the overall cognitive status (MoCA scores), female patients with T2D had signif-
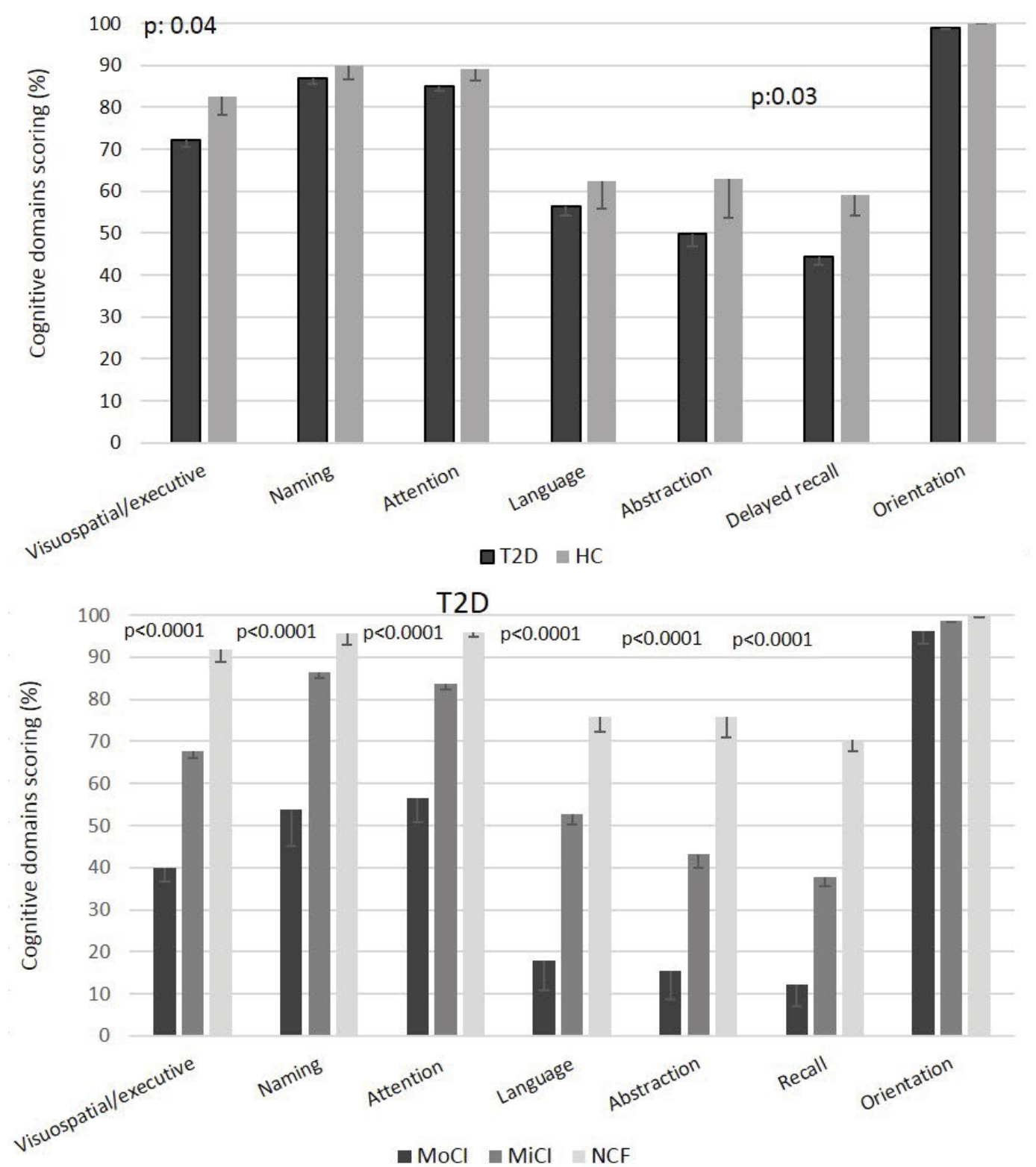

Figure 2. Scoring for cognitive domains evaluated by MoCA test a. in patients with T2D (black bars) vs HC (grey bars); b. in patients with T2D with moderate cognitive impairment (MoCI), mild cognitive impairment (MiCI) and normal cognitive function (NCF) (data represent mean \pm SE) 


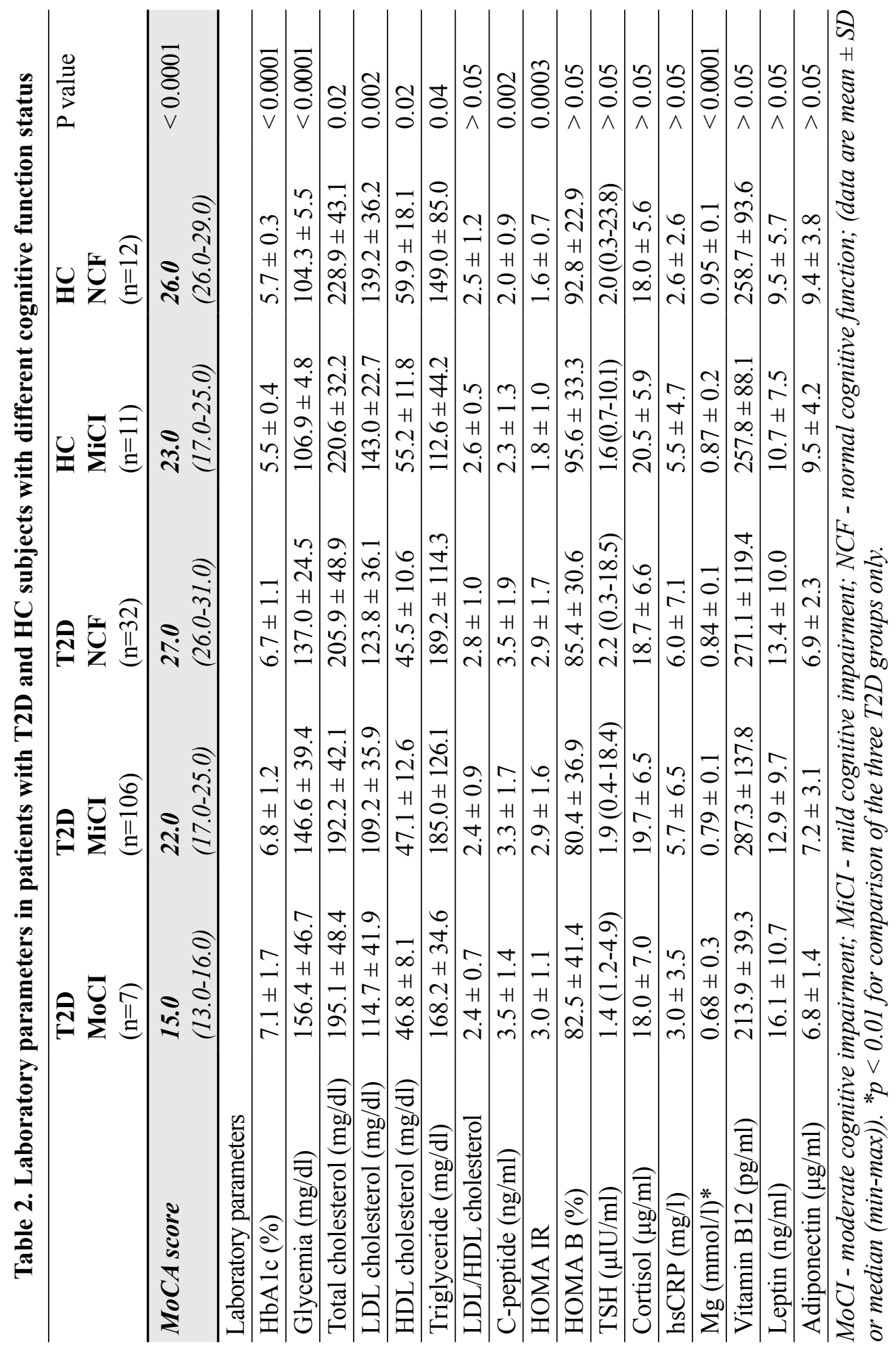


icantly lower scores for the visuospatial/ executive, naming and language domains compared with men $(4.0(0.0-5.0)$ points vs. $4.0(1.0-5.0)$ points, p: $0.003 ; 3.0(0.0-3.0)$ points vs. $3.0(1.0-$ $3.0)$ points, p: 0.02 and $1.0(0.0-3.0)$ points vs. $2.0(0.0-3.0)$ points, $\mathrm{p}: 0.005$, respectively) and higher scores for the delayed recall domain (3.0 (0.0-5.0) points vs. $2.0(0.0-5.0)$ points, p: 0.03). Age negatively correlated with the visuospatial/ executive and delayed recall domains $(-0.16$; 95\%CI: $-0.32 ; 0.00)$, p: 0.04 and $-0.22 ; 95 \% \mathrm{CI}$ : $-0.38 ;-0.06$, p: 0.005).

When the results were analyzed according to the cognitive function, patients with T2D with mild and moderate cognitive impairment presented dysfunctions in all but the orientation domain ( $p<0.0001$ for all) (Figure 2b), while HC group with mild cognitive impairment had lower scores in language and delayed recall domains compared with $\mathrm{HC}$ with normal cognitive function $(45.5 \%$ (1.4 out of 3 points) vs. $77.8 \%(2.3$ out of 3 points), p: 0.02 and $43.6 \%$ (2.2 out of 5 points) vs. $73.3 \%$ (3.7 out of 5 points), p: 0.005 , respectively) (Figure 2).

All HC subjects and 145 T2D patients had laboratory tests evaluation. The results are presented in Table 2. One cortisol value was excluded (outlier). Subjects with T2D had higher HbA1c, fasting blood glucose, triglyceride and fasting C-peptide levels, while HC subjects had higher total cholesterol, LDL- and HDL-cholesterol values (Table 2). In addition, patients with T2D had higher scores of insulin resistance (HOMA IR), while no significant difference was seen in beta cell function (HOMA B\%) (Table 2). Mean serum $\mathrm{Mg}$ levels were significantly different in the 5 groups $(p<0.0001$; Table 2$)$. The difference was statistically significant between the moderate cognitive impairment T2D group and both $\mathrm{HC}$ groups $(\mathrm{p}<0.05$ and $\mathrm{p}<0.01)$ and between the mild cognitive impairment T2D group and both HC groups $(\mathrm{p}<0.01$ and $\mathrm{p}<0.001)$.
When serum $\mathrm{Mg}$ levels were compared only between T2D groups, there was a significant difference $(\mathrm{p}<0.01)$, with both cognitive impairment groups having significantly lower $\mathrm{Mg}$ concentration vs. normal cognitive group $(\mathrm{p}<0.05$ for both). No other significant difference was noted for laboratory parameters between the three T2D groups (p: NS for all). Overall, patients with T2D had significantly lower serum $\mathrm{Mg}$ concentrations compared to matched-HC $(0.81(0.12-0.99)$ vs. $0.92(0.41-1.35) \mathrm{mmol} / \mathrm{l}, \mathrm{p}<0.0001)$. Female patients with T2D had significantly lower serum $\mathrm{Mg}$ levels compared to men $(0.80(0.12-0.99)$ vs. 0.83 (0.48-0.99) mmol/1, p: 0.03) (Table 2).

We further analyzed the correlation of MoCA scores with various metabolic, nutritional, hormonal, and immunologic laboratory parameters (Table 3). In subjects with T2D, the MoCA scores were positively correlated with serum $\mathrm{Mg}$ levels (0.24, 95\%CI: 0.07; 0.39; p: 0.003) (Figure 3).

No other significant correlations of MoCA scores were observed with the other laboratory measurements: $-0.04(95 \% \mathrm{CI}:-0.21 ; 0.12)$ for fasting blood glucose; -0.08 (95\% CI: -0.24 ; 0.08 ) for $\mathrm{HbA} 1 \mathrm{c} ; 0.13$ (95\% $\mathrm{CI}$ : $-0.02 ; 0.29)$ for total cholesterol; 0.13 (95\%CI: $-0.03 ; 0.29)$ for LDL cholesterol; 0.00 (95\%CI: -0.16 ; 0.16$)$ for HDL cholesterol; 0.08 (95\%CI: $-0.08 ; 0.24)$ for triglyceride; $0.02(95 \% \mathrm{CI}:-0.14 ; 0.19)$ for C-peptide; 0.008 (95\%CI: -0.15 ; 0.17) for TSH; $0.002(95 \% \mathrm{CI}$ : $-0.16 ; 0.17)$ for cortisol; 0.06 (95\%CI: $-0.10 ; 0.23)$ for hsCRP; 0.08 (95\%CI: $-0.08 ; 0.24)$ for vitamin $\mathrm{B} 12 ;-0.05(95 \% \mathrm{CI}$ : -0.22 ; 0.11$)$ for leptin; $-0.04(95 \% \mathrm{CI}$ : -0.21 ; 0.12 ) for adiponectin ( $\mathrm{p}: \mathrm{NS})$.

No significant correlations were found between MoCA score and cognitive domains, respectively with HOMA IR and HOMA B\% (data not shown). After adjustment for $\mathrm{HbAlc}$, LDL-cholesterol, HDL-cholesterol, triglyceride, TSH, cortisol, hsCRP, C-peptide, vitamin B12, leptin, adiponectin values in a multiple linear re- 


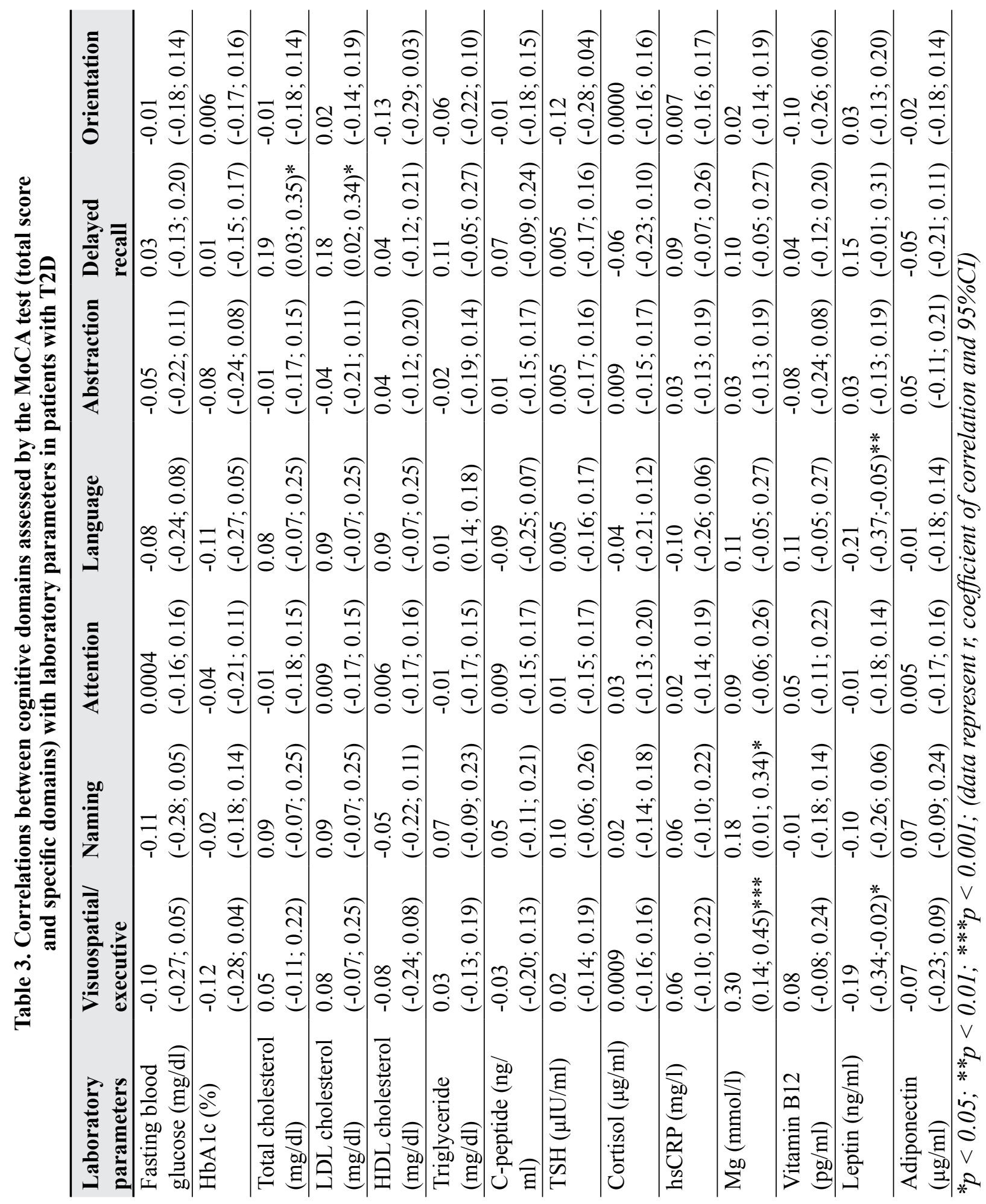




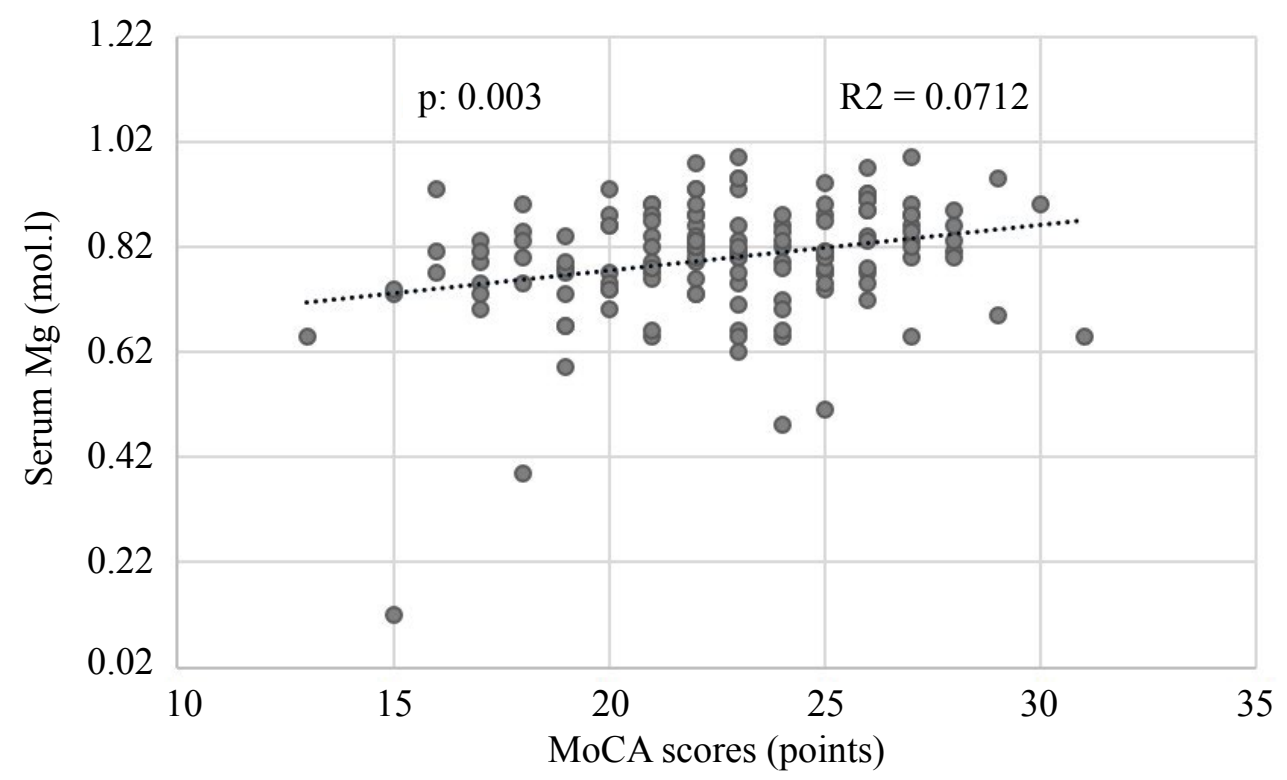

Figure 3. Correlation of serum Mg concentrations with cognitive function as evaluated by the MoCA test

gression analysis, $\mathrm{Mg}$ and age remained significantly correlated with MoCA scores (p: 0.04).

Finally, we analyzed the correlation of each laboratory parameter with each cognitive domain assessed by the MoCA test (Table 3). In patients with T2D total cholesterol and HDL-cholesterol significantly correlated with delayed recall scores (p: 0.01 and p: 0.02, respectively; Table 3). Serum Mg levels correlated with visuospatial/ executive and naming scores (p: 0.0002 and p: 0.02, respectively; Table 3 ). In addition, a negative correlation of serum leptin levels and the scores of visuospatial/ executive and language domains was noted (p: 0.02 and p: 0.007, respectively; Table 3).

\section{Discussions}

Firstly, our study confirms that patients with T2D have significantly lower cognitive function scores compared with healthy individuals (along with high prevalence of cognitive impairment, as previously shown) (7). This indicates that the neuro- cognitive complications are important conditions that require attention in patients with T2D. The causes of the T2D-related cognitive impairment have not yet been fully clarified. Some research suggests that the neurodegenerative, cerebrovascular processes and associated brain atrophy might be the link to cognitive dysfunction $(8,9)$. Most probably, T2D is associated with a mixed pathology in the brain and no single specific vascular or metabolic risk factor has been identified as a determinant of accelerated cognitive decline, which is reported to be rather multifactorial $(10,11)$.

In our study, younger age and higher education significantly correlated with better cognitive function in patients with T2D, even if the MoCA test was already adjusted for the level of education. These results are consistent with those reported in other studies performed in subjects with T2D $(12,13)$.

In addition to having lower MoCA test scores, subjects with T2D performed worse in the visuospatial/ executive and delayed recall 
cognitive domains compared with healthy individuals. Other studies have indicated significant decline in several cognitive domains such as memory, executive function, language, processing speed and attention in patients with T2D, but findings were not uniform (14-16). This could be due to differences in the population group, cognitive evaluation, study design, or data analysis between studies. A recent study in Japanese patients with T2D that also employed the MoCA test to evaluate cognitive function/ domains has shown that patients with diabetes and mild cognitive impairment had lower scores for frontal lobe function (attention, language and abstraction) and delayed recall (17). Moreover, a recent systematic review and meta-analysis of 15 studies $(n=23796 ; 2370$ with T2D) has confirmed that T2D is associated with impairment in memory and executive function (18). A longitudinal study with a 12-year follow-up reported that individuals with T2D presented accelerated cognitive decline, mainly in the information-processing speed, executive function and delayed word recall compared with subjects without diabetes (19). Interestingly, another longitudinal study that evaluated the impact of transition in glucose status over 2 years, has demonstrated that individuals who presented incident glucose disorders had greater decline in global cognition and visuospatial function as well as in total brain volume, compared with normal (20). Apparently, various brain areas are involved in the visuospatial/ executive and delayed recall functions as assessed in the MoCA test (fronto-parieto-occipital cortices for the visuospatial/ executive function and hippocampal-parieto-frontal areas for retrieval memory, respectively) (21). Neuroimaging studies have shown that patients with T2D have global brain atrophy, but also regional atrophy in the hippocampus and prefrontal regions, which may explain at least in part the cognitive deficits seen in these patients $(9,13)$. In fact, there is some evidence that higher blood glucose levels, even in the normal range, are associated with atrophy in the hippocampus and amygdala, brain regions critically important for memory (22). Functional imaging data further suggests diminished connectivity between the hippocampus and the frontal and temporal regions (23). Thus, atrophy in the hippocampal area and altered neuronal connectivity might be responsible for the memory impairment in subjects with T2D (23).

We observed gender differences in cognitive domains evaluated by the MoCA test: female patients with T2D performed worse in the visuospatial/ executive, naming and language domains compared with men, but better in delayed recall function. The literature seems to suggest that there are gender differences in specific cognitive ability domains, that start early in life, as well as in the rate of cognitive decline, but this has been little studied in patients with T2D (24). An Israeli study noted similar findings in T2D patient: women outperformed men in memory functions, while men outperformed women in praxis (executive) and shape (attention) functions (12).

When we evaluated the correlations between the cognitive function and metabolic, nutritional, hormonal, and immunologic parameters in subjects with T2D, we only found positive association between serum $\mathrm{Mg}$ levels and cognitive function, which remained significant after adjustment for other parameters. Literature regarding the role of $\mathrm{Mg}$ in cognitive function of patients with T2D is relatively scarce. A few studies found correlations between low serum Mg levels and cognitive impairment in other diseases, including Alzheimer's disease (AD) $(25,26)$. Some data seem also to indicate low brain $\mathrm{Mg}$ levels in patients with $\mathrm{AD}$, although other studies have found no correlation between $\mathrm{Mg}$ and $\operatorname{AD}(27,28)$. A more recent longitudinal study in cognitively healthy individuals followed-up for 8 years showed that higher dietary $\mathrm{Mg}$ intake was associated with lower risk of mild cognitive impairment (29). The mechanisms by which $\mathrm{Mg}$ 
might protect from cognitive impairment are not entirely clear. Some in vitro and animal studies have shown that $\mathrm{Mg}$ is associated with reduced production and increased degradation of toxic hyperphosphorylated protein tau, modulation of amyloid-beta protein precursor processing, reduction of neuro-inflammation and protection of synaptic plasticity (30-33). T2D often seems to be accompanied by alteration of $\mathrm{Mg}$ status, with reduction of serum and intracellular free $\mathrm{Mg} \mathrm{lev-}$ els, which is associated with decreased insulin sensitivity (34). This might be one possible explanation for the observation that patients with T2D are at increased risk of cognitive impairment. We also noted lower serum $\mathrm{Mg}$ levels in T2D patients compared with healthy controls.

In addition, there were significant correlations between lower Mg levels and impairment of the visuospatial/ executive and naming domains in these patients. A recent study in older subjects with cognitive impairment showed that a compound containing a $\mathrm{Mg}$ salt improved the overall cognitive ability, the executive function and memory, but these results need further confirmation (35). Although lipid concentrations did not correlate with overall cognitive function, total and LDL-cholesterol levels were associated with delayed recall domain. The role of lipids in the development of cognitive dysfunction in patients with T2D remains unclear, as the results of observational and interventional studies are not uniform (2). A study in old non-demented adults showed that non-carriers of the ApoE4 allele with highest total and LDL-cholesterol had best memory scores, while another recent study indicated that LDL-cholesterol levels positively associated with memory $(36,37)$. A study in the LDL-receptor knock-out mice showed impaired spatial memory and increased synaptic deficits and apoptosis in the hippocampus (38). Cholesterol homeostasis and metabolism in the brain is complex and requires further investigations.
Finally, our results indicate a negative correlation between leptin and visuospatial/ executive and language functions. A study in older adults also showed a negative association between serum leptin levels and executive function, while the Edinburgh Type 2 Diabetes Study reported that higher leptin concentrations were associated with overall cognitive decline and poorer executive function performance only in men with T2D $(39,40)$. Further research is needed in order to elucidate the implications of leptin in various cognitive functions in subjects with diabetes.

Our study has certain limitations, but it also identifies areas for future research. Firstly, this was a single-center study with a relatively low number of healthy subjects that did not allow a full comparison with patients with T2D. Because of its cross-sectional design, the changes of the cognitive function/ domains in time, as well as the temporal relationship with laboratory parameters could not be evaluated. It would be interesting to assess these parameters in newly diagnosed T2D patients and monitor their change in time, along with the progressive deterioration of cognitive function/ domains. Another drawback is that we could not simultaneously study through imaging techniques the brain levels of various parameters (e.g. $\mathrm{Mg}$ ) and correlate them with the cognitive and laboratory results, but this could also be addressed by future research that could help elucidate the underlying mechanisms of T2D-related cognitive impairment. Finally, the monitoring of the efficacy of therapeutic interventions (e.g. Mg supplementation) on cognitive function or prevention of cognitive deterioration in patients with $\mathrm{T} 2 \mathrm{D}$ could be performed in future research.

\section{Conclusions}

Patients with T2D presented significant cognitive impairment, with decrements in the visu- 
ospatial/ executive and delayed recall cognitive domains. Female patients performed better than men in delayed recall function but worse in the visuospatial/ executive, naming and language domains. Younger age and higher education correlated with better cognitive function. Serum $\mathrm{Mg}$ levels were significantly lower in patients with T2D and correlated positively with the overall cognitive function, as well as with visuospatial/ executive and naming domains.

\section{Acknowledgments}

This study was supported by an Internal Research Grant of the University of Medicine and Pharmacy of Tîrgu Mureș, Romania (contract number 1/23.12.2014).

The authors thank Paula Beldean RN, Maria Mureşan RN, Mirela Pazstor RN, Ligia Coroş PharmD, Enikö Bakos RN and Adina Silaghi for technical assistance.

We do not have any conflict of interests to declare with regards to this work.

\section{References}

1. Reijmer YD, van den Berg E, Ruis C, Kappelle LJ, Biessels GJ. Co+gnitive dysfunction in patients with type 2 diabetes. Diabetes Metab Res Rev. 2010;26(7):507-19. DOI: 10.1002/dmrr.1112.

2. Feinkohl I, Price JF, Strachan MW, Frier BM. The impact of diabetes on cognitive decline: potential vascular, metabolic, and psychosocial risk factors. Alzheimers Res Ther. 2015;7(1):46. DOI: 10.1186/s13195-015-0130-5.

3. Bordier L, Doucet J, Boudet J, Bauduceau B. Update on cognitive decline and dementia in elderly patients with diabetes. Diabetes Metab. 2014;40(5):331-7. DOI: 10.1016/j.diabet.2014.02.002.

4. American Diabetes Association. Standards of Medical Care in Diabetes. Diabetes Care 2015;38(Suppl. 1):S41-S48.

5. Nasreddine ZS, Phillips NA, Bédirian V, Charbonneau S, Whitehead V, Collin I, et al. The Montreal Cognitive
Assessment, MoCA:A Brief Screening Tool For Mild Cognitive Impairment. J Am Geriatr Soc 53:695-699, 2005. DOI: $10.1111 /$ j.1532-5415.2005.53221.x.

6. HOMA software downloaded from site https://www. dtu.ox.ac.uk/homacalculator/download.php.

7. Cernea S, Zoltai C, Berbecilă D, Şular FL. Prevalence of depression, anxiety and cognitive impairment in patients with type 2 diabetes from the Central part of Romania. Acta Medica Marisiensis. 2016 Apr 27; [Epub ahead of print]. DOI: 10.1515/amma-2016-0014.

8. Mayeda ER, Whitmer RA, Yaffe K. Diabetes and cognition. Clin Geriatr Med. 2015;31(1):101-15. DOI: 10.1016/j.cger.2014.08.021.

9. Biessels GJ, Reijmer YD. Brain changes underlying cognitive dysfunction in diabetes: what can we learn from MRI? Diabetes. 2014;63(7):2244-52. DOI: $10.2337 / \mathrm{db} 14-0348$.

10. Jongen C, van der Grond J, Kappelle LJ, Biessels GJ, Viergever MA, Pluim JP. Utrecht Diabetic Encephalopathy Study Group. Automated measurement of brain and white matter lesion volume in type 2 diabetes mellitus. Diabetologia. 2007;50(7):1509-16. DOI: $10.1007 / \mathrm{s} 00125-007-0688-y$.

11. Reijmer YD, van den Berg E, de Bresser J, Kessels RP, Kappelle LJ, Algra A, et al. Utrecht Diabetic Encephalopathy Study Group. Accelerated cognitive decline in patients with type 2 diabetes:MRI correlates and risk factors. Diabetes Metab Res Rev. 2011;27(2):195-202. DOI: 10.1002/dmrr.1163.

12. Guerrero-Berroa E, Ravona-Springer R, Schmeidler J, Silverman JM, Sano M, Koifmann K, et al. Age, gender, and education are associated with cognitive performance in an older Israeli sample with type 2 diabetes. Int J Geriatr Psychiatry. 2014;29(3):299-309. DOI: $10.1002 /$ gps. 4008.

13. Hayashi K, Kurioka S, Yamaguchi T, Morita M, Kanazawa I, Takase H, et al. Association of cognitive dysfunction with hippocampal atrophy in elderly Japanese people with type 2 diabetes. Diabetes Res Clin Pract. 2011;94(2):180-5. DOI: 10.1016/j.diabres.2011.07.002.

14. Ruis C, Biessels GJ, Gorter KJ, van den Donk M, Kappelle LJ, Rutten GE. Cognition in the early stage of type 2 diabetes. Diabetes Care. 2009;32(7):1261-5. DOI: $10.2337 / \mathrm{dc} 08-2143$.

15. Fischer AL, de Frias CM, Yeung SE, Dixon RA. Short-term longitudinal trends in cognitive per- 
formance in older adults with type 2 diabetes. J Clin Exp Neuropsychol. 2009;31(7):809-22. DOI: $10.1080 / 13803390802537636$.

16. van den Berg E, Reijmer YD, de Bresser J, Kessels RP, Kappelle LJ, Biessels GJ. Utrecht Diabetic Encephalopathy Study Group. A 4 year follow-up study of cognitive functioning in patients with type 2 diabetes mellitus. Diabetologia. 2010;53(1):58-65. DOI: 10.1007/s00125-009-1571-9.

17. Mori Y, Futamura A, Murakami H, Kohashi K, Hirano T, Kawamura M. Increased detection of mild cognitive impairment with type 2 diabetes mellitus using the Japanese version of the Montreal Cognitive Assessment: A pilot study. Neurology and Clinical Neuroscience. 2015, 3(3):89-93. DOI: 10.1111/ncn3.153.

18. Sadanand S, Balachandar R, Bharath S. Memory and executive functions in persons with type 2 diabetes:a meta-analysis. Diabetes Metab Res Rev. 2016;32(2):13242. DOI: $10.1002 /$ dmrr.2664.

19. Spauwen PJ, Köhler S, Verhey FR, Stehouwer CD, van Boxtel MP. Effects of type 2 diabetes on 12-year cognitive change:results from the Maastricht Aging Study. Diabetes Care. 2013;36(6):1554-61. DOI: 10.2337/dc12-0746.

20. Samaras K, Lutgers HL, Kochan NA, Crawford JD, Campbell LV, Wen W, et al. The impact of glucose disorders on cognition and brain volumes in the elderly: the Sydney Memory and Ageing Study. Age (Dordr). 2014;36(2):977-93. DOI: 10.1007/s11357013-9613-0.

21. Julayanont P, Phillips N, Chertkow H, Nasreddine ZS. Montreal Cognitive Assessment (MoCA): Concept and Clinical Review. In Larner A. J. (ed). Cognitive Screening Instruments: A Practical Approach. 2013, Springer-Verlag, pp:111-51. DOI: 10.1007/978-14471-2452-8_6.

22. Cherbuin N, Sachdev P, Anstey KJ. Higher normal fasting plasma glucose is associated with hippocampal atrophy: The PATH Study. Neurology. 2012;79(10):101926. DOI: 10.1212/WNL.0b013e31826846de.

23. Jones N, Riby LM, Mitchell RL, Smith MA. Type 2 diabetes and memory: using neuroimaging to understand the mechanisms. Curr Diabetes Rev. 2014;10(2):11823. DOI: $10.2174 / 1573399810666140425160811$.

24. Li R, Singh M. Sex differences in cognitive impairment and Alzheimer's disease. Front Neuroendocrinol. 2014;35(3):385-403. DOI: 10.1016/j. yfrne.2014.01.002.
25. Corsonello A, Pedone C, Pahor M, Malara A, Carosella L, Mazzei B, et al. Gruppo Italiano di Farmacovigilanza nell'Anziano (GIFA). Serum magnesium levels and cognitive impairment in hospitalized hypertensive patients. Magnes Res. 2001;14(4):273-82.

26. Barbagallo M, Belvedere M, Di Bella G, Dominguez LJ. Altered ionized magnesium levels in mild-to-moderate Alzheimer's disease. Magnes Res. 2011;24(3):S115-21.

27. Andrási E, Páli N, Molnár Z, Kösel S. Brain aluminum, magnesium and phosphorus contents of control and Alzheimer-diseased patients. J Alzheimers Dis. 2005;7(4):273-84.

28. Gerhardsson L, Lundh T, Minthon L, Londos E. Metal concentrations in plasma and cerebrospinal fluid in patients with Alzheimer's disease. Dement Geriatr Cogn Disord. 2008;25(6):508-15. DOI: 10.1159/000129365.

29. Cherbuin N, Kumar R, Sachdev PS, Anstey KJ. Dietary Mineral Intake and Risk of Mild Cognitive Impairment: The PATH through Life Project. Front Aging Neurosci. 2014;6:4. DOI: 10.3389/fnagi.2014.00004.

30. Gómez-Ramos A, Domínguez J, Zafra D, Corominola $\mathrm{H}$, Gomis R, Guinovart JJ, et al. Inhibition of GSK3 dependent tau phosphorylation by metals. Curr Alzheimer Res. 2006;3(2):123-7. DOI: 10.2174/156720506776383059.

31. Yu J, Sun M, Chen Z, Lu J, Liu Y, Zhou L, et al. Magnesium modulates amyloid-beta protein precursor trafficking and processing. J Alzheimers Dis. 2010;20(4):1091-106.

32. Wang P, Yu X, Guan PP, Guo JW, Wang Y, Zhang Y, et al. Magnesium ion influx reduces neuroinflammation in A $\beta$ precursor protein/Presenilin 1 transgenic mice by suppressing the expression of interleukin-1 $\beta$. Cell Mol Immunol. 2015 Nov 9. [Epub ahead of print]. DOI: 10.1038/cmi.2015.93.

33. Xu ZP, Li L, Bao J, Wang ZH, Zeng J, Liu EJ, et al. Magnesium protects cognitive functions and synaptic plasticity in streptozotocin-induced sporadic Alzheimer's model. PLoS One. 2014;9(9):e108645. DOI: 10.1371/journal.pone.0108645.

34. Barbagallo M, Dominguez LJ. Magnesium and type 2 diabetes. World J Diabetes. 2015;6(10):1152-7. DOI: 10.4239/wjd.v6.i10.1152. 
35. Liu G, Weinger JG, Lu ZL, Xue F, Sadeghpour S. Efficacy and Safety of MMFS-01, a Synapse Density Enhancer, for Treating Cognitive Impairment in Older Adults: A Randomized, Double-Blind, PlaceboControlled Trial. J Alzheimers Dis. 2015;49(4):971-90. DOI: $10.3233 /$ JAD-150538.

36. West R, Beeri MS, Schmeidler J, Hannigan CM, Angelo $\mathrm{G}$, Grossman HT, et al. Better memory functioning associated with higher total and LDL cholesterol levels in very elderly subjects without the APOE4 allele. Am J Geriatr Psychiatry. 2008;16(9):781-5. DOI: 10.1097/ JGP.0b013e3181812790.

37. Leritz EC, McGlinchey RE, Salat DH, Milberg WP. Elevated levels of serum cholesterol are associated with better performance on tasks of episodic memory. Metab Brain Dis. 2016;31(2):465-73. DOI: 10.1007/ s11011-016-9797-y.
38. Wang SH, Huang Y, Yuan Y, Xia WQ, Wang P, Huang R. LDL receptor knock-out mice show impaired spatial cognition with hippocampal vulnerability to apoptosis and deficits in synapses. Lipids Health Dis. 2014;13:175. DOI: 10.1186/1476-511X-13-175.

39. Gunstad J, Spitznagel MB, Keary TA, Glickman E, Alexander T, Karrer J, et al. Serum leptin levels are associated with cognitive function in older adults. Brain Res. 2008;1230:233-6. DOI: 10.1016/j.brainres.2008.07.045.

40. Labad J, Price JF, Strachan MW, Deary IJ, Seckl JR, Sattar $\mathrm{N}$, et al. Edinburgh Type 2 Diabetes Study Investigators. Serum leptin and cognitive function in people with type 2 diabetes. Neurobiol Aging. 2012;33(12):2938-41. DOI: 10.1016/j.neurobiolaging.2012.02.026. 